\title{
G-Protein Types Involved in Calcium Channel Inhibition at a Presynaptic Nerve Terminal
}

\author{
Rukmini R. Mirotznik, Xu Zheng, and Elis F. Stanley \\ Synaptic Mechanisms Section, National Institute of Neurological Disorders and Stroke, National Institutes of Health, \\ Bethesda, Maryland 20892
}

The inhibition of presynaptic calcium channels via G-proteindependent second messenger pathways is a key mechanism of transmitter release modulation. We used the calyx-type nerve terminal of the chick ciliary ganglion to examine which G-proteins are involved in the voltage-sensitive inhibition of presynaptic $\mathrm{N}$-type calcium channels. Adenosine caused a prominent inhibition of the calcium current that was totally blocked by pretreatment with pertussis toxin (PTX), consistent with an exclusive involvement of $\mathrm{G}_{\mathrm{o}} / \mathrm{G}_{\mathrm{i}}$ in the $\mathrm{G}$-protein pathway. Immunocytochemistry was used to localize these G-protein types to the nerve terminal and its transmitter release face. We used two approaches to test for modulation by other G-protein types. First, we treated the terminals with ligands for a variety of G-proteinlinked neurotransmitter receptor types that have been associated with different G-protein families. Although small inhibitory effects were observed, these could all be eliminated by PTX, indicating that in this terminal the $\mathrm{G}_{\mathrm{i}}$ family is the sole transmitter-induced G-protein inhibitory pathway. Second, we examined the kinetics of calcium channel inhibition by uncaging the nonselective and irreversible G-protein activator GTP $\gamma \mathrm{S}$, bypassing the receptors. A large fraction of the rapid GTP $\gamma$ S-induced inhibition persisted, consistent with a $G_{0} / G_{i}$-independent pathway. Immunocytochemistry identified $G_{q}, G_{11}, G_{12}$, and $G_{13}$ as potential PTXinsensitive second messengers at this terminal. Thus, our results suggest that whereas neurotransmitter-mediated calcium channel inhibition is mainly, and possibly exclusively, via $G_{o} / G_{i}$, other rapid PTX-insensitive G-protein pathways exist that may involve novel, and perhaps transmitter-independent, activating mechanisms.

Key words: nerve terminal; G-protein; G-protein type; calcium channel; presynaptic; calcium channel modulation; calcium channel inhibition; transmitter release; synaptic strength; chick; calyx synapse; chick ciliary ganglion
The inhibition of presynaptic calcium channels via trimeric G-protein second messenger pathways is a key mechanism whereby transmitter release, and hence, synaptic strength can be modulated (Hille, 1994). However, relatively little is known about which specific G-proteins are involved in this pathway in intact nerve terminals. We have used the large presynaptic nerve terminal of the chick ciliary ganglion to examine the diversity of G-protein types involved in calcium channel regulation.

The chick calyx nerve terminal preparation (Stanley and Goping, 1991) has several key advantages for an analysis of G-protein action. First, it is sufficiently large to allow direct recording of whole-cell calcium currents. Second, the channels are almost exclusively N-type (Stanley, 1991; Yawo and Momiyama, 1993) and located in the presynaptic region (Stanley, 1993; Haydon et al., 1994). Third, the large size allows protein components to be localized to the surface membrane by immunocytochemistry and,

Received June 5, 2000; revised July 24, 2000; accepted July 27, 2000.

This work was supported by Canadian Institute for Health Research Award FRN 38091. We are indebted to gifts of antibodies from Drs. J. K. Northup (Nationa Institute on Deafness and Other Communication Disorders) and J. S. Gutkind (National Institute of Dental Research) and to suggestions from Drs. J. K. Northup (National Institutes of Health) and J. Mitchell (Department of Pharmacology, University of Toronto).

R.M. and X.Z. contributed equally to this work.

Correspondence should be addressed to Dr. Elis F. Stanley, Head, Cellular and

Molecular Biology Division, Toronto Western Research Institute, MP14-320, 399 Bathurst Street, Toronto, Ontario M5T 2S8, Canada. E-mail: estanley@uhnres. utoronto.ca.

Dr. Stanley's present address: Cellular and Molecular Biology Division, Toronto Western Research Institute Toronto, Canada.

Dr. Mirotznik's present address: National Institutes of Health, National Institute of Neurological Disorders and Stroke, Building 36, Room 5B21, Bethesda, MD 20892-1408.

Dr. Zheng's present address: National Institutes of Health, National Institute of Neurological Disorders and Stroke, Building 10/5N250, 10 Center Drive, MSB-1408, Bethesda, MD 20892-1408.

Copyright (C) 2000 Society for Neuroscience $0270-6474 / 00 / 207614-08 \$ 15.00 / 0$ by costaining for vesicle clusters, to the transmitter release site regions (Stanley and Mirotznik, 1997).

The N-type calcium channel is known to be sensitive to transmitter-mediated, G-protein-dependent, inhibition (for review, see Dolphin, 1998; Ikeda and Dunlap, 1999). A major element of this inhibition is via a voltage-sensitive mechanism (Bean, 1989) that can be relieved, and hence assayed, by a strong preceding depolarizing pulse (Grassi and Lux, 1989; Elmslie, 1990).

There is considerable diversity in G-protein pathways leading to $\mathrm{N}$-type calcium channel inhibition. A wide range of metabotropic receptor types may be involved, and a number of different G-proteins are capable of acting as second messengers, indicating a high level of heterogeneity. The pertussis toxin (PTX)-sensitive G-proteins $G_{o}$ and $G_{i}$ are the most commonly identified types in both primary neurons (Diversé-Pierluissi and Dunlap, 1993; Hille, 1994; Filippov et al., 1998; Park and Dunlap, 1998) and cell lines (Toth et al., 1996; Morikawa et al., 1998). However, PTXinsensitive G-proteins can also modulate these channels. Thus, $\mathrm{G}_{\mathrm{s}}$ can modulate $\mathrm{N}$-type channels in rat sympathetic neurons ( $\mathrm{Zhu}$ and Ikeda, 1994), $G_{13}$ does so in the NG 108-15 cell line (WilkBlaszczak et al., 1994), and $G_{z}$ will substitute for PTX-sensitive G-proteins when overexpressed in superior cervical ganglia neurons (Jeong and Ikeda, 1998).

The presynaptic calcium channels in the chick calyx are inhibited via a G-protein-dependent pathway. Adenosine, a potent modulator of transmitter release at a variety of synapses, inhibits N-type calcium channels (Yawo and Chuhma, 1993). G-protein-dependent, voltage-sensitive inhibition of the calcium channels has been shown directly using the nonhydrolyzable (and irreversible) GTP analog GTP $\gamma$ S (Stanley and Mirotznik, 1997).

The goal of this study was to determine which G-protein type or types modulate presynaptic N-type calcium channels at the chick calyx synapse. Our results indicate that extracellular transmitters, including adenosine, all appear to act via $G_{\mathrm{o}} / \mathrm{G}_{\mathrm{i}}$. However, we also demonstrate that other classes of G-protein are present, and we present evidence that one or more of these can also inhibit presynaptic calcium channel activity. 
Table 1. Antibodies used in this study

Antibody

Poly anti-G $\alpha_{\mathrm{o} / \mathrm{i}}$

Poly anti-G $\alpha_{\mathrm{il}-3}$

Poly anti-G $\alpha_{\mathrm{o}+\mathrm{i} 3}$

Poly anti-G $\alpha_{\mathrm{i} 3}$

Mono anti- $\mathrm{G} \alpha_{\mathrm{o}}(\mathrm{Ab}-1)$

Mono anti-G $\alpha_{\mathrm{o}}(\mathrm{Ab}-2)$

Mono anti-G $\alpha_{\mathrm{i} 1}$

Mono anti-G $\alpha_{\mathrm{i} 2}$

Poly anti-G $\alpha_{\mathrm{q} / 11}$

Poly anti-G $\alpha_{\mathrm{q} / 11}$

Poly anti-G $\alpha_{\mathrm{q} / 11}$

Poly anti-G $\alpha_{12,13}$

Poly anti-G $\alpha_{\mathrm{s}}$

Poly anti-G $\alpha_{\mathrm{z}}$

Mono SV2

Poly SV2A

Mono neurofilament

Mono tubulin $\alpha$

Mono tubulin $\beta$

Source

Western blot dilution

J. K. Northup

Santa Cruz (sc262)

DuPont (NEI-803)

Calbiochem (371729)

Lab Vision

Lab Vision

Lab Vision

Lab Vision

DuPont

Calbiochem

Santa Cruz

Gutkind

DuPont

Calbiochem

DSHB

StressGen

DSHB

Lab Vision

Lab Vision
Immunostain dilution

1:1000

$1: 100$

1:100

$1: 100$

1:200

1:200

1:100

1:100

1:100

$1: 100$

1:100

$1: 100$

$1: 100$

$1: 100$

1:0-1:1

1:200

$1: 1$

1:100

1:100
$1: 1000$

$1: 1000$

1:1000

$1: 1000$

1:1000

$1: 1000$

$1: 1000$

$1: 1000$

$1: 1000$

$1: 1000$

1:1000

$1: 1000$

1:500

\section{MATERIALS AND METHODS}

\section{Electrophysiology}

Calyx nerve terminal preparation. Ciliary ganglia were removed from embryonic day 15 (E15) chicks and were enzymatically dissociated in minimal Eagle's medium (MEM), as previously described (Stanley and Goping, 1991; Haydon et al., 1994). The dissociated preparation was transferred to a coverslip recording chamber containing the external solution, and calyx nerve terminals were identified visually under high-power magnification with oil-immersion lenses $(40-60 \times ; 1.35-1.4$ numerical aperture). The cells were washed three times in MEM before use.

Patch-clamp recording. Currents were recorded using the whole-cell variant of the patch-clamp technique. Patch electrodes $(1.5 \mathrm{~mm}$ outside diameter, thin wall microcapillary glass; World Precision Instruments), were fire-polished and had resistances in the range of 3.5-4.5 $\mathrm{M} \Omega$ when filled with the internal solution described below. Currents were amplified, and cell membrane capacitance and series resistance were electronically compensated (Axopatch 200A; Axon Instruments, Foster City, CA). Voltage protocol generation and data acquisition were performed using pClamp 7.0 software. Current traces were generally low-pass filtered at 5 $\mathrm{kHz}$, and leak currents were subtracted with a standard $\mathrm{P} / 6$ protocol, using a positive polarity leak subtraction pulse. All recordings were performed at room temperature.

The external (bath) medium was (in mM): $\mathrm{NaCl} 160, \mathrm{CaCl}_{2} 5, \mathrm{MgCl}_{2} 1$, D-glucose 5, 4-aminopyridine 2, tetrodotoxin 0.001, HEPES-Na 10, and the patch electrode internal solution was: Cs-gluconate $120, \mathrm{CsCl} 10$, EGTA-Cs $10, \mathrm{MgCl}_{2} 1$, HEPES-Cs 10 , tetraethylamonium-Cl 20, MgATP 1 , with GTP 0.1 (except where specified). GTP $\gamma \mathrm{S}(0.1 \mathrm{mM})$ was included in the internal solution as described. PTX treatment was performed by incubating the preparation at $20^{\circ} \mathrm{C}\left(8 \% \mathrm{CO}_{2}\right)$ in MEM overnight with or without $0.5-10 \mu \mathrm{g} / \mathrm{ml}$ PTX (Research Biochemicals, Natick, MA). Overnight incubation reduced the number of available calyx terminals for recording, consistent with the degeneration of the nerve stump after nerve section (Stanley and Drachman, 1980), and greatly increased the difficulty of these experiments. For flash photolysis, release of intracellular GTP $\gamma \mathrm{S}$, $S$-DMNPE-caged GTP $\gamma \mathrm{S}(400 \mu \mathrm{M}$; Molecular Probes, Eugene, OR) was added to the internal solution, and a single $200 \mathrm{msec}$ flash of unfiltered light from a mercury bulb (Uniblitz shutter; 40×; 1.35 NA quartz objective) was used to liberate the free nucleotide.

Voltage protocol and data analysis. A double trial protocol was used to measure voltage-sensitive G-protein inhibition. The cells were held at -80 $\mathrm{mV}$. In the first trial a single $80 \mathrm{msec}$ test pulse to $0 \mathrm{mV}$ activated a calcium current. In the second trial, delivered $5 \mathrm{sec}$ later, the test pulse was preceded by a $60 \mathrm{msec}$ depolarization to $+80 \mathrm{mV}$, a conditioning pulse that maximally relieves prepulse-sensitive G-protein inhibition in this nerve terminal (Stanley and Mirotznik, 1997). Data were acquired at 5-10 sec intervals. Current recruitment was measured as the maximal difference between the amplitude of the current induced by the test pulse with and without the conditioning pulse, at $\sim 10 \mathrm{msec}$ after the onset of the test pulse. Data were analyzed using ClampFit 6.0 (pClamp suite) and are presented as mean \pm SEM. Student's $t$ test was used to determine statistical significance.

Drug treatments. Drugs were dissolved in external solution and were applied either by addition to the bath or by pulse-triggered pressure ejection (Medical Systems) from a puff pipette ( $\sim 5 \mu \mathrm{m}$ diameter) at a distance of $\sim 10 \mu \mathrm{m}$. The chamber was not perfused because only one calyx was treated in each dish, and the recordings were typically of short duration and with few individual drug applications. The following G-protein receptor agonists were used: substance P, bradykinin, somatostatin, neuropeptide Y (Peninsula), BRL52537 (Tocris), VIP, serotonin, ATP (Sigma, St. Louis, MO), adenosine, and noradrenalin (Research Biochemicals). The drugs were diluted in external solution and were applied by a pneumatic pressure ejection from a closely positioned micropipette or by addition to the bath.

\section{Immunocytochemistry}

Antibody characterization. Primary G-protein antibodies (Table 1) were characterized by standard Western blot (10\% SDS gel) techniques. After electrophoresis, the proteins were transferred onto nitrocellulose membrane and probed with the indicated G-protein antibodies. Western blots were visualized with enhanced chemiluminescence.

G-protein antibodies used in this study are listed in Table 1. All primary antibodies were first tested for cross-reactivity against chick G-proteins by Western blot against chick brain protein $(10 \mu \mathrm{g} /$ lane; Fig. $1 A)$. We only relied on antibodies that gave bands restricted to the appropriate molecular weight for the $\mathrm{G} \alpha$ subunit $(\sim 40 \mathrm{kDa})$.

The specificity of each antibody for its particular G-protein subtype was tested against the following individual recombinant $\mathrm{G} \alpha$ subunits (Calbiochem, La Jolla, CA): $\mathrm{G}_{\mathrm{o}}, \mathrm{G}_{\mathrm{s}}, \mathrm{G}_{\mathrm{q}}, \mathrm{G}_{11}, \mathrm{G}_{\mathrm{i} 1}, \mathrm{G}_{\mathrm{i} 2}$, and $\mathrm{G}_{\mathrm{i} 3}$ (Fig. 1 B, panels 1-12). Anti-G $\alpha_{\mathrm{z}}$ was tested against all of these plus a mix of G-proteins (Calbiochem) reported to contain $\mathrm{G} \alpha_{\mathrm{i} 1-3}, \mathrm{G} \alpha_{\mathrm{o}}, \mathrm{G} \alpha_{\mathrm{s}}, \mathrm{G} \alpha_{\mathrm{z}}, \mathrm{G} \alpha_{\beta} \mathrm{s}$, and $\mathrm{G} \alpha_{\gamma}$ (Fig. $1 B$, panel 12). The $\mathrm{G}_{12,13}$ antibody was tested against the above single recombinant G-proteins plus recombinant $\mathrm{G}_{13}$ (Calbiochem) (Fig. 1B, panel 10). Recombinant $\mathrm{G} \alpha_{12}$ was unavailable.

On the whole, the antibodies distinguished far better between G-protein families $\left(G_{o} / G_{i}, G_{s}, G_{q / 11}\right.$ and $\left.G_{12 / 13}\right)$ than between members of the same family (Fig. 1B, panels 1-12). We made considerable effort to differentiate between specific PTX-sensitive members of the $G_{\mathrm{o}} / G_{\mathrm{i}}$ family $\left(\mathrm{G}_{\mathrm{o}}, \mathrm{G}_{\mathrm{i} 1}, \mathrm{G}_{\mathrm{i} 2}\right.$, and $\mathrm{G}_{\mathrm{i} 3}$ ). Monoclonal antibodies against $\mathrm{G} \alpha$ (Fig. 1 B, lanes 1,2) and $\mathrm{G} \alpha_{\mathrm{i}}$ (data not shown) were particularly selective, but of these only the anti-G $\alpha_{\mathrm{o}}$ antibodies were of use for immunocytochemistry. Commercially available polyclonal anti-G-protein antibodies for particular members of the $G_{o} / G_{i}$ group typically exhibited little specificity and cross-reacted with all members (Fig. $1 B$, panels $4-6$ ). Although we were unable to obtain recombinant $\mathrm{G} \alpha_{\mathrm{z}}$ to test the anti-G $\alpha_{\mathrm{z}}$ antibody, our evidence suggests that this antibody was specific because a band of the appropriate molecular weight was observed against the $\mathrm{G} \alpha_{\mathrm{z}}$-containing mixture of G-proteins, whereas none was observed with any of the other recombinant G-proteins alone (Fig. 1B, panel 12).

Immunostaining of calyx nerve terminals. Ganglia from E15 chicks were dissociated and plated on coverslips, as described above. The preparation was fixed in $2 \%$ paraformaldehyde for $45 \mathrm{~min}$ and then permeabilized in $0.5 \%$ polyoxyethylene-20-cetyl ether with $0.5 \%$ paraformaldehyde for 10 min. Cells were stained by exposure to primary antibodies overnight. To identify the nerve terminal and the transmitter release zones, all preparations were double-labeled with the appropriate complimentary monoclonal or polyclonal antibody against the synaptic vesicle protein SV2 (Table 1). 


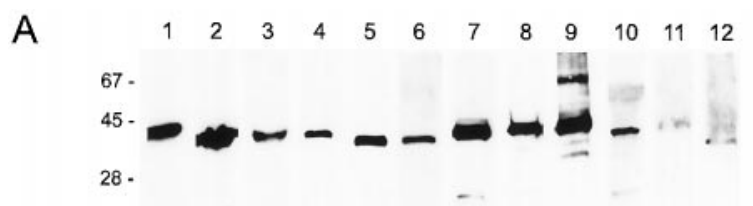

B

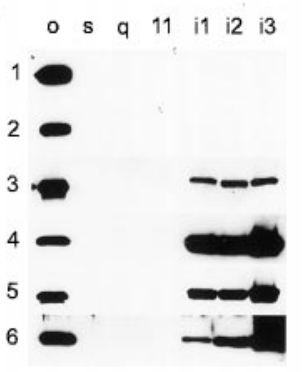

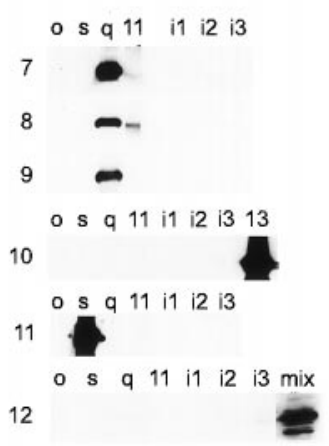

Figure 1. Characterization of G-protein antibodies. A, All antibodies gave an appropriate $\sim 40 \mathrm{kDa}$ band for chick brain protein (10 $\mu \mathrm{g} /$ lane). Lane 1 , Monoclonal anti- $\mathrm{G}_{\mathrm{o}}$ (Ab-1); 2, monoclonal anti- $\mathrm{G}_{\mathrm{o}}$ (Ab-2); 3, polyclonal anti-G (J. K. Northup); 4, polyclonal anti- $\mathrm{G}_{\text {i }}$ (Calbiochem); 5, polyclonal anti- $\mathrm{G}_{\mathrm{i} 1-3}$ (Santa Cruz Biotechnology); 6, polyclonal anti- $\mathrm{G}_{\mathrm{o}+\mathrm{i} 3}$ (DuPont); 7 , polyclonal anti- $\mathrm{G}_{\mathrm{q} / 11}$ (DuPont); 8 , polyclonal anti-G $\mathrm{G}_{\mathrm{q} / 11}$ (Santa Cruz Biotechnology); 9, polyclonal anti-G $\mathrm{q} / 11$ (Calbiochem); 10, polyclonal anti-G ${ }_{12}{ }_{13}$ (Gutkind); 11, polyclonal anti- $\mathrm{G}_{\mathrm{s}}$ (DuPont); 12, polyclonal anti- $\mathrm{G}_{\mathrm{z}}($ Calbiochem). $B$, Blot of antibodies against the recombinant $\mathrm{G} \alpha$ subunits: $\mathrm{G}_{\mathrm{o}}, \mathrm{G}_{\mathrm{s}}, \mathrm{G}_{\mathrm{q}}, \mathrm{G}_{11}, \mathrm{G}_{\mathrm{i} 1}$, $\mathrm{G}_{\mathrm{i} 2}, \mathrm{G}_{\mathrm{i} 3}$, and $\mathrm{G}_{13}$, as well as a G-protein mixture that includes $\mathrm{G}_{\mathrm{z}}$.

FITC and LRSC-conjugated secondary antibodies (Jackson ImmunoResearch, West Grove, PA) were applied at 1:50 dilution for $1 \mathrm{hr}$. Definitive localization of staining to the transmitter release face or the external, Schwann cell face of the nerve terminal was only possible in the dissociated preparations when the calyces remained attached to the postsynaptic ciliary neuron.

Immunostaining was also performed on ciliary ganglia slices prepared by cryostat section, without previous treatment with dissociation enzymes. Ganglia were fixed in $4 \%$ paraformaldehyde in $15 \%$ picric acid for $1-1 \frac{1}{2}$ $\mathrm{hr}$, infiltrated with $15 \%$ sucrose for $1 \mathrm{hr}$ and $30 \%$ sucrose overnight, and were then sliced on a cryostat into $12 \mu \mathrm{M}$ sections. Staining was performed as above and, except where noted, the staining patterns between dissociated cells and cryostat cells were consistent.

Dissociated cells and cryostat slices were visualized under fluorescent illumination on a Zeiss Axiophot with a 63 or $100 \times, 1.4$ NA lens. Images were acquired and analyzed using a Scanalytics Cellscan deconvolution system as described (Juhaszova et al., 2000). This system uses Exhaustive Photon Reassignment to yield confocal-like images of slices through the sample. At least 30 calyces were examined for each stain combination.

\section{RESULTS}

\section{Detection of G-protein-dependent inhibition of presynaptic calcium channels}

The object of this study was to determine which G-protein families are involved in the modulation of calcium currents in the presynaptic terminal of the chick ciliary ganglion. G-protein-dependent inhibition was monitored as the percentage of current increase after a strong depolarizing prepulse (Fig. 2) and is termed here the "prepulse recruitment." There was no evidence of calcium channel inhibition in the absence of intracellular GTP (Fig. 2, top left panel).

\section{Adenosine modulates presynaptic calcium channels via a PTX-sensitive G-protein pathway}

Transmitter-induced inhibition of calcium channels can involve many different G-protein species, the most common of which appear to be $G_{o}$ and $G_{i}$. Adenosine, which inhibits $N$-type calcium channels in many neuronal cells, is believed to act solely via $G_{o} / G_{i}$, and this agent inhibits calcium influx at the calyx nerve terminal (Yawo and Chuhma, 1993). Thus, our first objective was to demonstrate that this inhibition involved a characteristic voltagesensitive inhibition mechanism. We then tested if the adenosine
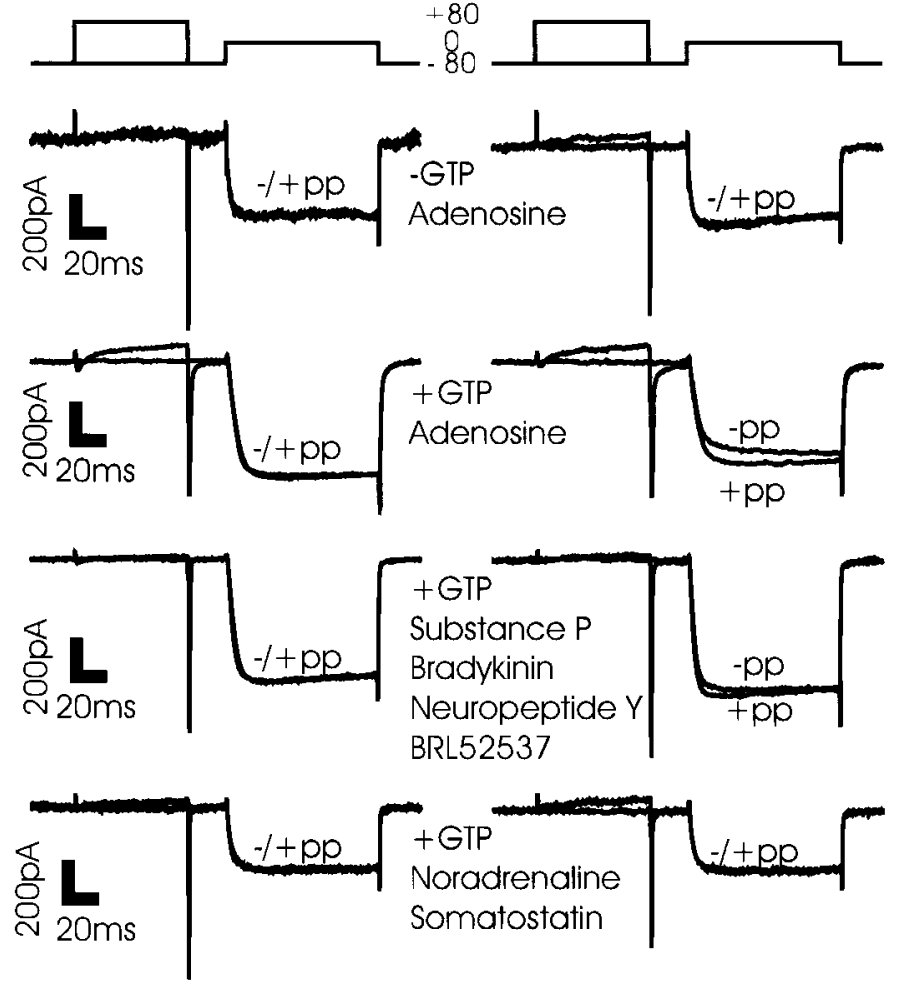

Figure 2. Modulation of chick ciliary ganglion presynaptic calcium current by neurotransmitter. The degree of current recruitment was determined using a double-trial protocol (see Materials and Methods) before, during, and after a puff of transmitter onto the terminal. Each panel shows before (left column) and during (right column) transmitter application in a single calyx nerve terminal. GTP (0.1 mM) was included in the internal solution in all experiments except in panel 1. Panel 1, Adenosine $(10 \mu \mathrm{M})$ in the absence of internal GTP. Panel 2, Adenosine $(10 \mu \mathrm{M})$ treatment. Panel 3, Treatment with a mix of substance $\mathrm{P}(0.5 \mu \mathrm{M})$, bradykinin $(1 \mu \mathrm{M})$, neuropeptide Y $(0.1 \mu \mathrm{M})$, and BRL52537 $(1 \mu \mathrm{M})$. Panel 4, Treatment with a mix of noradrenaline $(100 \mu \mathrm{M})$ and somatostatin $(10 \mu \mathrm{M}) .-p p$, Without prepulse; $+p p$, with prepulse.

inhibition pathway was via $\mathrm{G}_{\mathrm{o}} / \mathrm{G}_{\mathrm{i}}$ by blocking these $\mathrm{G}$-proteins with the selective toxin PTX.

A step voltage depolarization of the calyx nerve terminal triggered a calcium current with characteristic properties of rapid activation with little inactivation during the current pulse, terminated by a rapid, monotonic tail current on return to the resting potential (Fig. 2, left column). In the absence of drug treatment with or without intracellular GTP (Fig. 2, left column) or in the presence of adenosine but while omitting intracellular GTP (Fig. 2, top right panel), little or no prepulse recruitment was observed. However, when adenosine $(10 \mu \mathrm{M})$ was puff-applied in the presence of intracellular GTP (Fig. 2, second panel) a brief puff application caused a significant calcium current inhibition and a prepulse recruitment of $16.1 \pm 2.7 \%,(n=9)$, consistent with voltagesensitive inhibition via the G-protein pathway. Inhibition was maintained only during the $5 \mathrm{sec}$ puff application but persisted beyond the puff with longer treatment durations that can be attributed to extracellular accumulation. Repeated applications did not show significant desensitization (Fig. $3 A$ ).

We next tested for $\mathrm{G}_{\mathrm{o}} / \mathrm{G}_{\mathrm{i}}$ involvement in the adenosine pathway by pretreatment with PTX. Block with PTX typically requires hours of exposure necessitating the development of a method for long-term maintenance of the dissociated calyces. After $\sim 15 \mathrm{hr}$ incubation (in $\mathrm{MEM}$ at $20^{\circ} \mathrm{C}, 8 \% \mathrm{CO}_{2}$ ) nerve terminals survived but were less common and were more fragile. Control calyces were incubated in the same conditions in the absence of PTX. In these a prominent inward calcium current was still present, and adenosine-dependent prepulse recruitment was similar to calyces before incubation at $13.6 \pm 2.4 \%(n=6 ; p>0.05)$. PTX was tested 


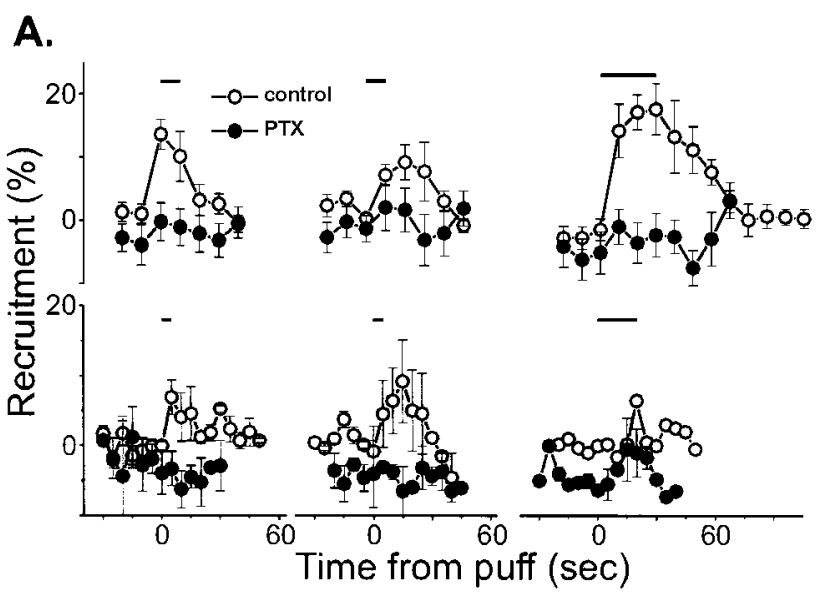

B.

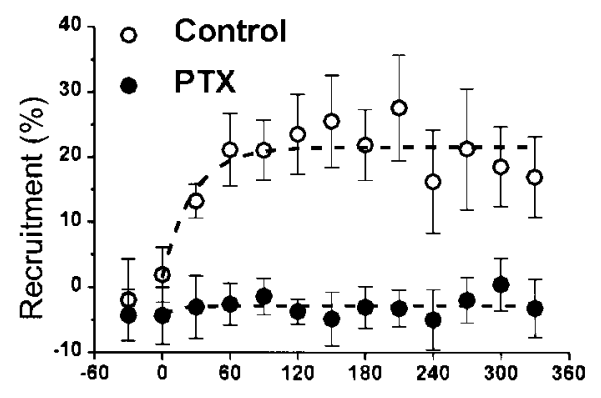

Time from bath addition (sec)

Figure 3. Effect of PTX pretreatment on adenosine-induced calcium current inhibition. $A$, Time course of calcium channel inhibition with puff application of transmitter (horizontal bar) with or without overnight PTX treatment. The effects of three consecutive trials given $\sim 1$ min apart to each group of calyces are shown. Top series, Adenosine $(10 \mu \mathrm{M})$ treatment (control, $n=6$; PTX, $n=14$ ). Bottom series, Treatment with a cocktail of substance $\mathrm{P}(0.5 \mu \mathrm{M})$, bradykinin $(1 \mu \mathrm{M})$, neuropeptide $\mathrm{Y}(0.1 \mu \mathrm{M})$, and BRL52537 (1 $\mu \mathrm{M}$; control, $n=4$; PTX, $n=3)$. B. Bath application of adenosine. Current inhibition was monitored after the addition $(t=0)$ of adenosine $(0.2 \mathrm{mM}$ ) to control (open symbols, $n=6$ ) or PTX-treated ( filled symbols, $n=6$ ) calyces. In both $A$ and $B$ current inhibition is monitored by the percentage of prepulse recruitment.

at concentrations ranging from 0.5 to $10 \mu \mathrm{g} / \mathrm{ml}$ but was fully effective at $1 \mu \mathrm{g} / \mathrm{ml}$. Pretreatment with PTX reduced adenosineinduced prepulse recruitment to undetectable levels at $1.6 \pm 2.2 \%$ $(n=14$; Fig. $3 A)$.

In an attempt to saturate the effect of adenosine, we bath-applied the transmitter at a high concentration $(0.2 \mathrm{~mm})$. In the absence of PTX, adenosine treatment for $\sim 2$ min resulted in $23.5 \pm 6.1 \%$ $(n=8)$ prepulse recruitment, which was maintained for up to $6 \mathrm{~min}$ without significant desensitization (Fig. $3 B$ ). PTX pretreatment eliminated prepulse recruitment $(-2.6 \pm 3.2 \% ; n=6 ; p<0.01$; Fig. $3 B$ ). Thus, adenosine inhibits the calcium current via a $\mathrm{G}_{\mathrm{o} / \mathrm{i}}$ pathway, in agreement with findings from other preparations.

\section{$\mathrm{G}_{\mathrm{o}} / \mathrm{G}_{\mathrm{i}}$ are located in the presynaptic nerve terminal}

We used high-resolution immunocytochemistry to determine whether $G_{o} / G_{i}$ proteins were present in the calyx. The $G_{i}$ protein family comprises $\mathrm{G}_{\mathrm{o} 1}, \mathrm{G}_{\mathrm{o} 2}, \mathrm{G}_{\mathrm{i} 1}, \mathrm{G}_{\mathrm{i} 2}, \mathrm{G}_{\mathrm{i} 3}, \mathrm{G}_{\mathrm{z}}, \mathrm{G}_{\mathrm{t} 1}, \mathrm{G}_{\mathrm{t} 2}$, and $\mathrm{G}_{\text {gust }}$. $G_{o}, G_{i}$ and $G_{z}$ have been implicated in the modulation of N-type calcium channels. With the exception of $G_{z}$, all are blocked by PTX. The synaptic vesicle marker SV2 was used to positively identify calyx nerve terminals, and the bright patches of staining for this protein mark the clusters of vesicles at the transmitter release sites.

We examined calyces that remained attached to a postsynaptic neuron and also those that had become fully detached. The former provides a view of the target protein locations at an intact synapse,

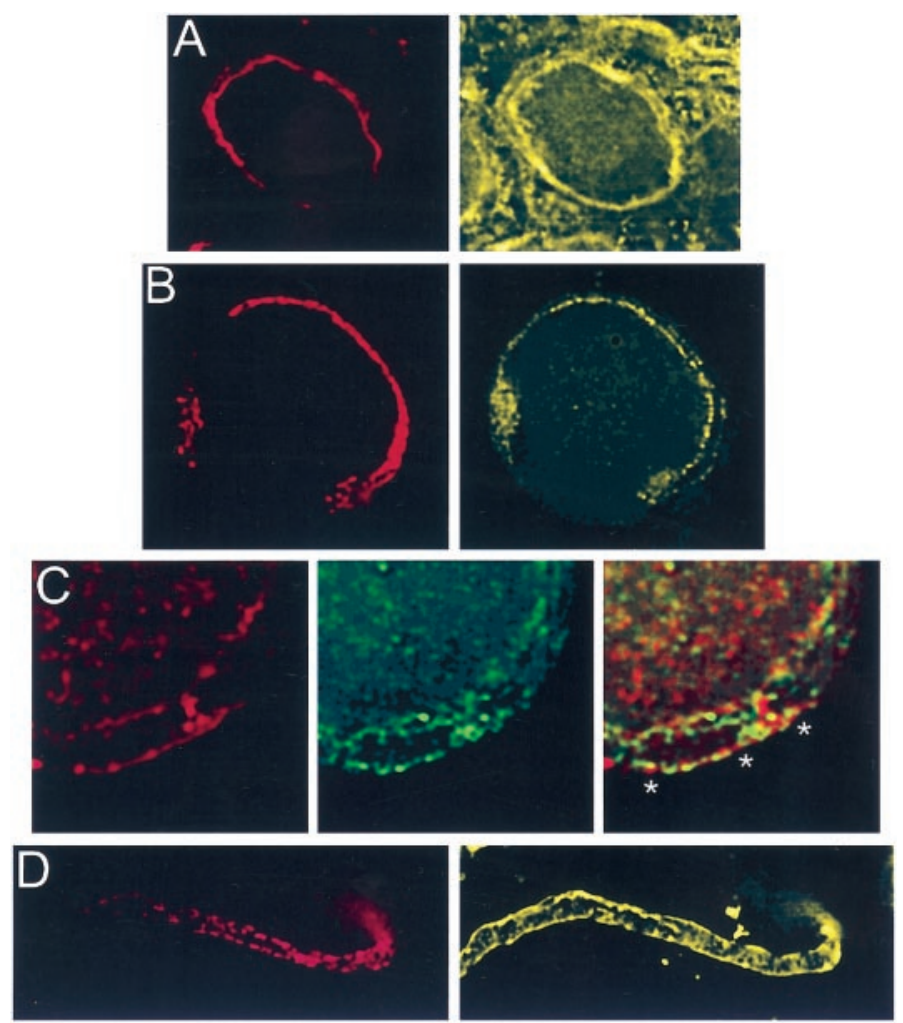

Figure 4. Localization of PTX-sensitive G-proteins. $\mathrm{G} \alpha_{\mathrm{o}}$ and $\mathrm{G} \alpha_{\mathrm{i}}$ localized to the membrane of the calyx presynaptic terminal. Calyx terminals are identified by SV2 (red) in the left panel of each pair except in $C . A$, Monoclonal antibodies (Ab-1 + Ab-2, yellow) localized $\mathrm{G}_{\mathrm{o}}$ to the membrane of calyx terminals in cryostat sections of whole ciliary ganglia. $B$, In dissociated preparations, monoclonal anti-G $\alpha_{\mathrm{o}}(\mathrm{Ab}-2)$ stained the membranes of presynaptic calyces with especially bright, patchy staining at the synaptic interface. $C, \mathrm{G}_{\mathrm{i}}$ was localized by a multistaining approach. $\mathrm{G}_{\mathrm{o}}$ plus $\mathrm{G}_{\mathrm{i}}$ were stained in red with polyclonal anti-G $\alpha_{\mathrm{o}}$ (Northup; red; left panel) whereas $G_{o}$ was stained in green with monoclonal anti-G $\alpha_{\mathrm{o}}$ (Ab-1 plus Ab-2; middle panel). Both labeled the calyx membrane. Superimposing the two stains (right panel) localizes Go by the costained regions (yellow). The distinct regions of red staining (e.g., asterisks) identify membrane regions with $\mathrm{G}_{\mathrm{i}}$ but not $\mathrm{G}_{\mathrm{o}}$. D, Fully isolated nerve terminals exhibited staining of the surface membrane with polyclonal anti-G $\alpha_{\mathrm{o}}$ (Northup), confirming a presynaptic localization of $\mathrm{G}_{\mathrm{o}} / \mathrm{G}_{\mathrm{i}}$.

whereas the latter can be used to demonstrate unambiguously that the G-protein is located in the presynaptic terminal and that we are not observing staining in the synaptic space or on the surface of the postsynaptic ciliary neuron. We also examined staining in calyces from whole fixed cryostat-sectioned ciliary ganglion (Fig. 4A). With this technique we were able to reproduce the main features of our findings in the absence of enzymatic dissociation.

$\mathrm{G}_{\mathrm{o}}$ was localized with two different monoclonal antibodies (Ab-1 and $\mathrm{Ab}-2)$. These antibodies gave essentially the same staining pattern in cryostat sections (Fig. $4 A$ ) and in dissociated ganglia (Fig. $4 B$ ). Staining was almost exclusively on the surface membrane of both the back (Schwann cell) and release-face aspects of the terminal, with particularly bright, patchy staining at the synaptic interface. We could not find an antibody suitable for selective immunostaining of chick $\mathrm{G}_{\mathrm{i}}$. However, a polyclonal antibody, anti$\mathrm{G} \alpha_{\mathrm{o} / \mathrm{i}}$ (Table 1), recognized $\mathrm{G}_{\mathrm{o}}$ and all three $\mathrm{G}_{\mathrm{i}} \alpha$ subunits (Fig. $1 B$, panel 3). If we assume that the monoclonal antibodies against $G_{o}$ localize all of this $\mathrm{G}$-protein, then the distribution of $\mathrm{G}_{\mathrm{i}}$ (or, more accurately, the $G_{i}$ that is not colocalized with $G_{o}$ ) can be deduced as the regions stained with anti-G $\alpha_{\mathrm{o} / \mathrm{i}}$ but not with either of the monoclonal antibodies. Thus, in Figure $4 C, \mathrm{G}_{\mathrm{o}} / \mathrm{G}_{\mathrm{i}}$ is stained in red (left panel), $\mathrm{G}_{\mathrm{o}}$ in green (middle panel), and costained regions are yellow in the superimposed images (right panel). While much of the $\mathrm{G}_{\mathrm{o}} / \mathrm{G}_{\mathrm{i}}$ and $\mathrm{G}_{\mathrm{o}}$ staining is colocalized and indistinguishable from $\mathrm{G}_{\mathrm{o}}$ alone, some distinct regions of red staining at the calyx mem- 
brane were evident (asterisks). These spots were seen near the vesicle clusters and are consistent with the presence of $G_{i}$ at the transmitter release face of the calyx nerve terminal.

In fully isolated nerve terminals anti-G $\alpha_{\mathrm{o} / \mathrm{i}}$ staining was noted primarily on the surface membrane (Fig. 4D). Staining partially corresponded with SV2 staining, indicating the presence of $G_{0} / G_{i}$ at the transmitter release sites, but with a distribution that also extended to nonterminal regions. Other polyclonal antibodies against $G_{o} / G_{i}$ gave similar results (data not shown).

\section{Calcium channel inhibition by metabotropic neurotransmitter receptors}

Whereas the inhibition of N-type calcium channels via the adenosine pathway involves primarily the PTX-sensitive members of the $\mathrm{G}_{\mathrm{i}}$ family, other metabotropic receptor types are known to use G-protein from different families (for review, see Hille et al., 1995). As a first attempt to identify inhibitory pathways that involved other G-protein types, we screened a number of different receptor agonists for voltage-dependent inhibition of the calcium channels. Ligands were puff-applied, and we tested for the presence of prepulse-dependent calcium current recruitment.

A mix (combined to speed the screening process) of substance $\mathrm{P}$ $(0.5 \mu \mathrm{M})$, neuropeptide $\mathrm{Y}(0.1 \mu \mathrm{M})$, bradykinin $(1 \mu \mathrm{M})$, and BRL52537 $(1 \mu \mathrm{M})$ resulted in a weak, but significant, current recruitment $(7.0 \pm 2.4 \%, n=4, p<0.05$; Figs. 2 , third panel, $3 A)$. Current inhibition by this cocktail was, however, also blocked by PTX pretreatment (Fig. $3 A$ ) and, hence, was also consistent with the involvement a $\mathrm{G}_{\mathrm{o}} / \mathrm{G}_{\mathrm{i}}$ pathway. Other receptor ligands including noradrenaline $(100 \mu \mathrm{M})$ and somatostatin $(3 \mu \mathrm{M}$; Fig. 2, bottom panel), VIP, ATP, or serotonin (both $10 \mu \mathrm{M}$; data not shown) did not inhibit the calcium current. Thus, this approach failed to demonstrate the involvement of other G-protein types. In fact, our findings suggest that the PTX-sensitive $G_{o} G_{i}$ may mediate all neurotransmitter-induced, voltage-sensitive calcium channel inhibition via G-proteins at this nerve terminal.

\section{Calcium channel inhibition by GTP $\gamma \mathbf{S}$}

We used GTP $\gamma \mathrm{S}$ to test if there was any evidence for calyx calcium channel inhibition by non- $\mathrm{G}_{\mathrm{o}} / \mathrm{G}_{\mathrm{i}} \mathrm{G}$-proteins. GTP $\gamma \mathrm{S}$ is a nonhydrolyzable analog of GTP that irreversibly activates all trimeric G-proteins and has been demonstrated to strongly inhibit the calcium channels at this nerve terminal (Stanley and Mirotznik, 1997). Our strategy was to first compare adenosine and GTP $\gamma$ Sdependent calcium channel inhibition and then to test for persisting GTP $\gamma \mathrm{S}$ inhibitory effects after $\mathrm{G}_{\mathrm{o}} / \mathrm{G}_{\mathrm{i}}$ block with PTX.

Infusion of GTP $\gamma \mathrm{S}(0.1 \mathrm{~mm})$ into the untreated calyx terminals resulted in a robust and maintained prepulse-sensitive calcium channel inhibition (Fig. 5A; Stanley and Mirotznik, 1997). The degree of current inhibition was double that observed with bath application of adenosine (GTP $\gamma \mathrm{S}$ : $47.1 \pm 12.6 \%, n=5$; adenosine: $23.5 \pm 6.1 \%, n=8$ as above, $p<0.01$ ), suggesting that GTP $\gamma \mathrm{S}$ activates a larger pool of inhibitory trimeric G-proteins than adenosine. This conclusion was supported by the finding that, in contrast to the results with adenosine, almost half of the GTP $\gamma \mathrm{S}$-induced current inhibition persisted after PTX pretreatment of the nerve terminals (Fig. $3 A ; 18.2 \pm 4.1 \%, n=6$ ).

The above results suggest, but do not prove, that the more pronounced calcium channel inhibition observed with GTP $\gamma$ S than adenosine is attributable to non $-\mathrm{G}_{\mathrm{o}} / \mathrm{G}_{\mathrm{i}}$ pathways. Although it is known that GTP $\gamma \mathrm{S}$ can still activate PTX-inhibited G-protein, published evidence suggests that its action is markedly slowed (see Discussion). We therefore compared the kinetics of GTP $\gamma \mathrm{S}$ dependent inhibition with or without previous PTX treatment using flash photolysis of caged GTP $\gamma \mathrm{S}$ (Dolphin et al., 1988). No prepulse-sensitive calcium channel inhibition was detected before flash treatment (Fig. $5 B$ ). In control terminals flash photolysis resulted in significant prepulse-dependent calcium current recruitment $(23.8 \pm 6 \%, n=7)$. Maximum inhibition was detected within $5 \mathrm{sec}$, the interval between trials. The effect of flash photolysis after PTX was essentially indistinguishable, with a prepulse-dependent
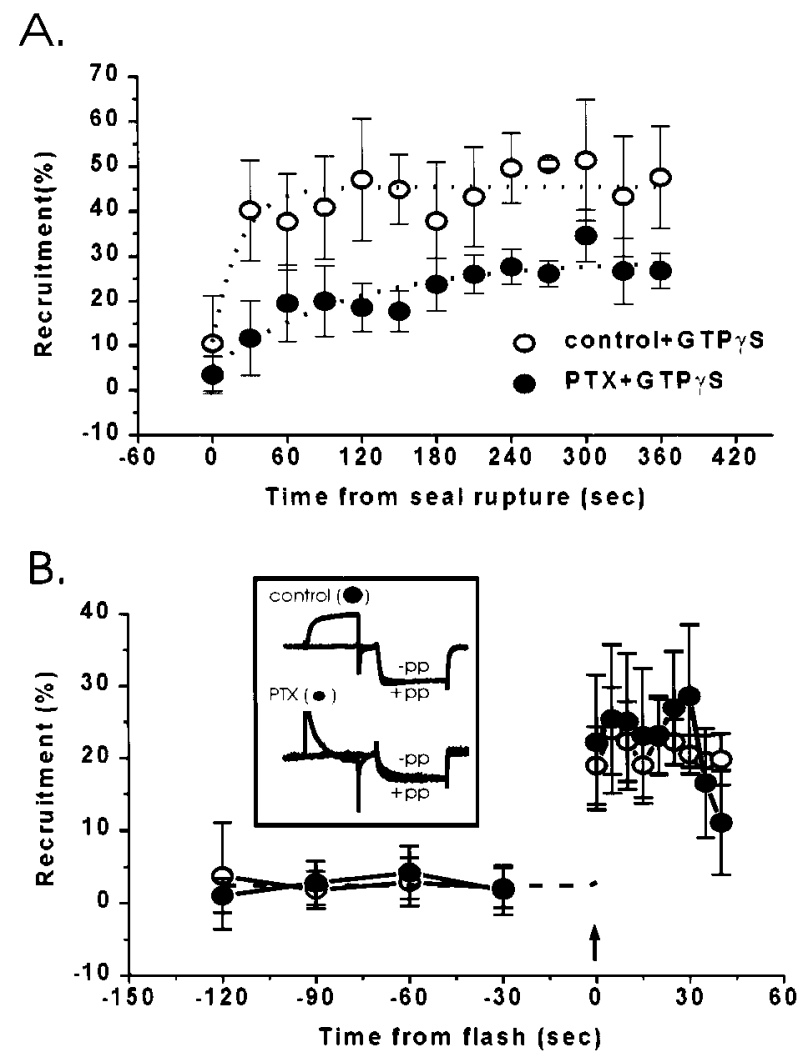

Figure 5. Effect of PTX pretreatment on GTP $\gamma \mathrm{S}$-induced calcium channel inhibition. $A$, Intracellular infusion of GTP $\gamma$ S. Calcium currents were recorded every $10 \mathrm{sec}$ after membrane rupture in each experiment, and the percentage of recruitment was averaged for $30 \mathrm{sec}$ periods. Control, $n=5$ experiments (open symbols); PTX, $n=6$ (closed symbols). B, Flash photolysis of caged GTP $\gamma \mathrm{S}$ with or without PTX pretreatment. Caged GTP $\gamma \mathrm{S}$ was included in the internal solution, and $\sim 2$ min after membrane seal rupture the caged nucleotide was released by a $200 \mathrm{msec}$ flash (arrow). Immediately after, current trials were initiated (control, $n=7$; PTX, $n=$ 5). Insert, Representative current traces recorded 5-10 sec after the flash in a control and a PTX-treated terminal. $-p p$, Without prepulse; $+p p$, with prepulse. Symbols as in $A$.

recruitment of $25.5 \pm 4 \%(n=5)$ and an abrupt onset within the first $5 \mathrm{sec}$. An anomaly in these results was that the amplitude of inhibition with flash photolysis was significantly less than that observed when (free) GTP $\gamma \mathrm{S}$ was introduced directly into the nerve terminal. We do not know the reason for this disparity but it may reflect, in part, the liberation of a lower concentration of intracellular GTP $\gamma \mathrm{S}$ from the caged compound or perhaps a component that is inhibited with a much slower time constant (possibly via recruitment of PTX-inhibited $\mathrm{G}_{\mathrm{o}} / \mathrm{G}_{\mathrm{i}}$ ) than could not be reliably detected within the limitations of the uncaging technique. Because of the technical difficulty of these experiments (see Materials and Methods) these possibilities were not examined further. The important point was, however, that rapid inhibition could still be detected, even after PTX treatment, in stark contrast to the findings with adenosine.

\section{PTX-insensitive G-proteins localized at the presynaptic nerve terminal}

We used immunocytochemistry to test for the presence and distribution in the calyx nerve terminal of PTX-insensitive G-proteins in the $G_{\mathrm{q}}, G_{12}$, and $G_{\mathrm{s}}$ families and also for $G_{z}$, a PTX-insensitive member of the $G_{i}$ family.

Members of the $G_{q}$ subfamily were examined with three polyclonal antibodies that cross-reacted with $\mathrm{G} \alpha_{\mathrm{q}}$ and $\mathrm{G} \alpha_{11}$ (Table 1, Fig. 1), and all three gave similar staining patterns at the calyx nerve terminal. The results obtained with the DuPont (Billerica, MA) antibody are presented. Attached calyces had staining throughout the nerve terminal that often colocalized with SV2 

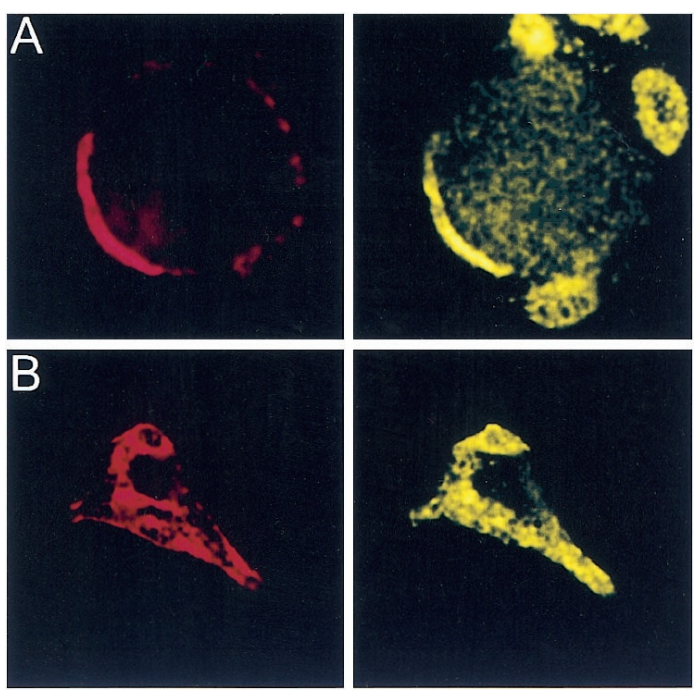

Figure 6. Localization of PTX-insensitive G-proteins: $\mathrm{G}_{\mathrm{q} / 11} \cdot \mathrm{G}_{\alpha \mathrm{q} / 11}$ (DuPont antibody) localized to the membrane and cytoplasm of the presynaptic terminal. Calyx terminals were identified by SV2 (red) in the left panel. Attached $(A)$ and isolated $(B)$ calyces had bright staining throughout the terminal that frequently colocalized with SV2.

(Fig. 6A) and was particularly bright at the synaptic interface. Fully isolated calyx nerve terminals also exhibited spotty staining that localized to both the membrane and the cytoplasm (Fig. 6B).

The $\mathrm{G}_{12}$ subfamily of G-proteins contains two members, $\mathrm{G}_{12}$ and $\mathrm{G}_{13}$, and our antibody recognized both (Fig. 1). With most attached calyces, the staining of the presynaptic terminal was comparable in intensity to the postsynaptic soma and thus difficult to distinguish. However, some somata were less brightly stained, and the calyx could then be seen to exhibit clear spotty staining throughout the terminal (Fig. $7 A$ ). However, unlike $\mathrm{G}_{\mathrm{o}}$ or $\mathrm{G}_{\mathrm{q} / 11}$, prominent staining of the synaptic interface was not observed. Fully isolated calyces stained both at the terminal region, as identified by the SV2 staining, and further up the length of the axon (Fig. $7 B$ ).

The $G_{s}$ family contains $G_{\text {olf }}$ and $G_{s}$. We only investigated $G_{s}$ staining because the former is expressed solely in the olfactory system. An antibody that recognized only $\mathrm{G} \alpha_{\mathrm{s}}$ (Fig. $1 B$, panel 11) produced bright staining of the soma that rivaled that of the calyx (Fig. 8A). The staining was, if anything, reduced along the synaptic interface. This impression was supported by the observation that in fully isolated calyx nerve terminals, punctate $\mathrm{G}_{\mathrm{s}}$ staining was
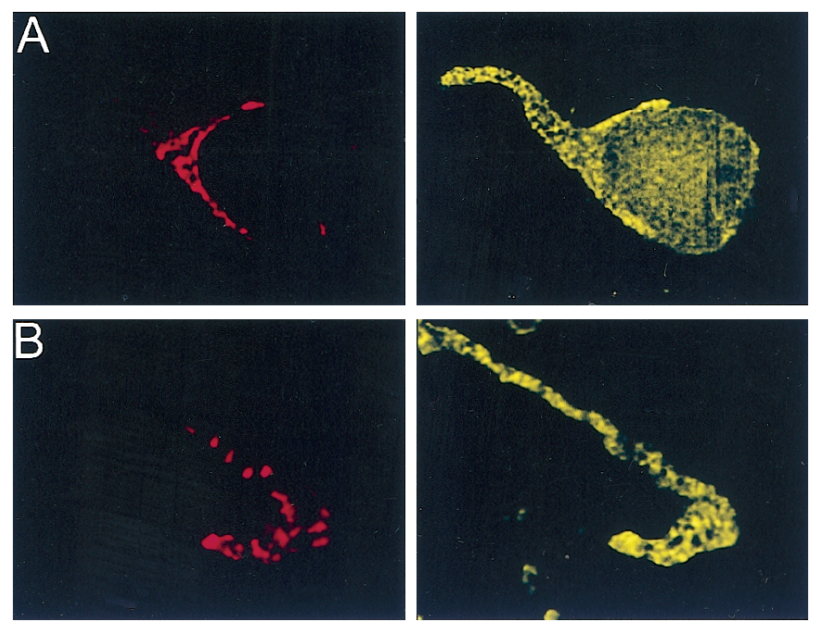

Figure 7. Localization of PTX-insensitive G-proteins: $\mathrm{G}_{12,13} \cdot \mathrm{G}_{\alpha 12,13}$ localized to both the membrane and cytoplasm of the calyx terminal. Calyx terminals are identified by SV2 (red) in the left panel. A, Attached calyces had spotty staining throughout the membrane and the cytoplasm. $B$, The staining remained in isolated calyces.
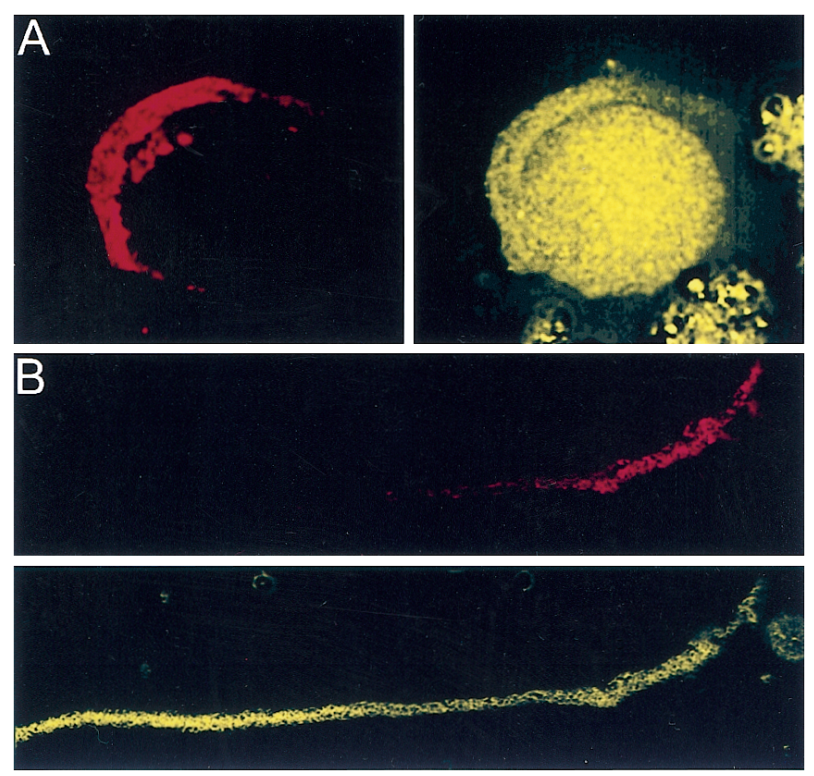

Figure 8. Localization of PTX-insensitive G-proteins: $\mathrm{G}_{\mathrm{s}} \cdot \mathrm{G}_{\alpha \mathrm{s}}$ predominantly localized to the calyx cytoplasm. Calyx terminals are identified by SV2 (red) in each panel pair. A, Attached calyces were as stained as the postsynaptic neuron with reduced staining at the interface. $B$, Isolated calyces showed bright $G_{\alpha \mathrm{S}}$ staining along the axon that decreased at the terminal region.

negatively correlated with SV2 staining and, thus, with the presynaptic region (Fig. $8 B$ ).

Anti-G $\alpha_{z}$ gave a novel staining pattern, not seen for any other $\mathrm{G}$-protein. Staining was limited to a bright fibrous band that coursed through the cytoplasm of the calyx axon and into the terminal (Fig. 9A,B). Staining for $\mathrm{G}_{\mathrm{z}}$ and SV2 were mutually exclusive, and no clear $G_{z}$ staining was associated with the surface membrane in the nerve terminal. In the postsynaptic soma, the stained fibrous pattern formed a faint web-like pattern just beneath the membrane that came together to course out of the soma and stream down the axon (data not shown). Because this pattern of staining was strongly suggestive of the cytoskeleton, we colabeled $\mathrm{G}_{\mathrm{z}}$ with cytoskeletal proteins. $\mathrm{G}_{\mathrm{z}}$ did not colocalize with tubulin $\alpha$ or $\beta$ (Fig. $9 C$ shows tubulin $\alpha$ ) but exhibited near perfect colocalization with the phosphorylated $200 \mathrm{kDa}$ subunit of neurofilament protein (Fig. 9D). This $\mathrm{G}_{\mathrm{z}}$ staining pattern was not attributable to cross-reaction of the antibody with chick neurofilament protein because Western blots for the antibody did not show a $200 \mathrm{kDa}$ band (data not shown) or, for that matter, any band other than the G-protein itself (Fig. 1).

\section{DISCUSSION}

We have examined the diversity of G-proteins involved in the voltage-dependent modulation of N-type calcium channels at an identified presynaptic nerve terminal. Our main findings are first, numerous G-proteins from several families exist at this nerve terminal but that only certain types are closely associated with the transmitter release face. Second, PTX-sensitive members of the $\mathrm{G}_{\mathrm{i}}$ family are involved in the adenosine-dependent, and possibly all, neurotransmitter-induced calcium channel inhibition. Third, we present evidence that PTX-independent G-proteins can also modulate the presynaptic calcium channels, although their role in nerve terminal function remains to be established.

The isolated chick calyx synapse preparation exhibits several methodological advantages for the study of presynaptic calcium channels and their modulation. These include excellent visualization of the whole nerve terminal and the ability to achieve an effective voltage clamp of membrane currents. Furthermore, immunofluorescent staining can be performed on cryostat sections, dissociated calyx synapses free from surrounding cells, and even 

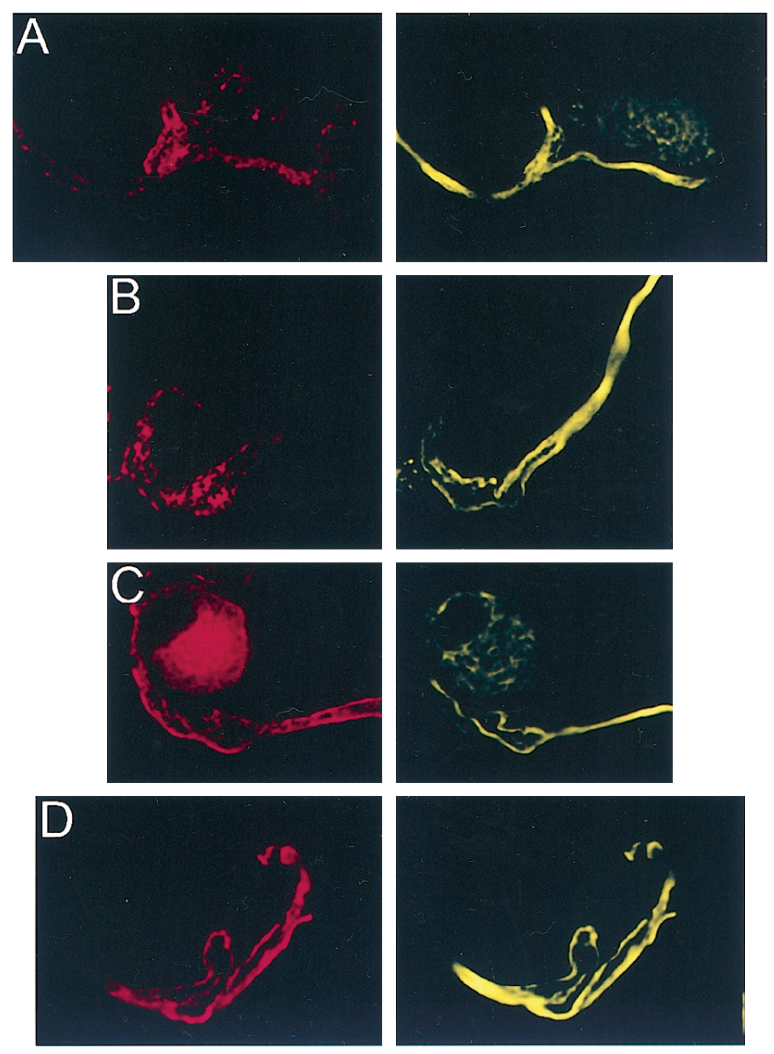

Figure 9. Localization of PTX-insensitive G-proteins: $\mathrm{G}_{\mathrm{z}}$. Attached $(A)$ and isolated $(B)$ calyces had bright fibrous staining for $\mathrm{G}_{\mathrm{z}}$ that coursed through the axon and partially into the terminal and was inversely correlated with SV2 (red, left panel). This staining pattern was suggestive of colocalization with the cytoskeleton. $C$, Tubulin $\alpha$ (red, left panel) stained predominantly near the calyx membrane and, hence, did not colocalize with the predominantly intracellular staining of $\mathrm{G}_{\mathrm{z}}$ (yellow; right panel). D, $\mathrm{G}_{\mathrm{z}}$ showed almost perfect colocalization (yellow, right panel) with the phosphorylated $200 \mathrm{kDa}$ subunit of neurofilament protein (red, left panel).

fully isolated nerve terminals, ensuring unambiguous localization of staining to the nerve terminal.

Adenosine-induced calcium current inhibition was demonstrated to occur via a PTX-sensitive pathway. $\mathrm{G}_{\mathrm{o}}$ was localized to the membrane of the calyx nerve terminal (Fig. $4 A, B$ ), and evidence was presented for similar localization of $\mathrm{G}_{\mathrm{i}}$ (Fig. $4 C$ ). Thus, we conclude that one or both of these G-protein species mediate the adenosine inhibitory pathway at the calyx presynaptic nerve terminal.

The involvement of PTX-insensitive G-proteins in calcium channel inhibition was initially tested by treating the nerve terminal with a variety of neurotransmitters that have been associated with non$\mathrm{G}_{\mathrm{o}} / \mathrm{G}_{\mathrm{i}}$ inhibitory pathways. Ligands for noradrenaline, somatostatin, $\mathrm{P} 2_{\mathrm{Y}}$, muscarinic, VIP, serotonin, substance P, NPY, bradykinin, and $\kappa$-opiate G-protein receptors were tested. However, minimal inhibition of the calcium channels was observed, and even this was blocked by PTX. Thus, our results suggest that at this nerve terminal, neurotransmitter-dependent inhibition of presynaptic calcium channels occurs exclusively via the PTX-sensitive $\mathrm{G}$-proteins $\mathrm{G}_{\mathrm{o}}$ and $\mathrm{G}_{\mathrm{i}}$.

A more general test for $\mathrm{G}$-proteins involved in calcium channel inhibition was based on the nonselective G-protein activator GTP $\gamma$ S. Intracellular treatment with this agent caused a far greater calcium current inhibition $(\sim 40 \%)$ than that observed with a saturating dose of adenosine $(\sim 20 \%)$. This finding in itself suggests the recruitment of an additional pool of G-proteins. However, it does indicate whether the increased inhibition is attributable to the activation of additional, perhaps reserve, $G_{o} / G_{i}$ or the recruitment of distinct G-protein types.

To test for channel inhibition via non- $\mathrm{G}_{\mathrm{o}} / \mathrm{G}_{\mathrm{i}}$ G-proteins, we tested GTP $\gamma \mathrm{S}$ after PTX treatment. Although the degree of GTP $\gamma$ S-dependent calcium current inhibition was reduced, a significant level persisted. However, an alternative interpretation for this PTX-insensitive fraction is that GTP $\gamma \mathrm{S}$ overcomes the action of the toxin on $G_{o} / G_{i}$ and that calcium channel inhibition still involves these G-proteins. Early studies by Gilman (Katada et al., 1984) on purified G-proteins in vitro concluded that PTX treatment markedly impedes the activation of $\mathrm{G}_{\mathrm{i}}$ by GTP $\gamma \mathrm{S}$. However, a later report by Huff and Neer (1986) contradicted this finding, reporting that GTP $\gamma \mathrm{S}$ can overcome the inhibitory action of PTX. The anomaly in these two reports is readily attributable to differences in the assay conditions: the former study exposed the G-proteins to $\mathrm{GTP} \gamma \mathrm{S}$ for only $2 \mathrm{~min}$ at $30^{\circ} \mathrm{C}$ and, hence, tested only for shortterm effects. However, the study by Huff and Neer (1986) incubated GTP $\gamma \mathrm{S}$ with the G-proteins for $30 \mathrm{~min}$ at $30^{\circ} \mathrm{C}$ followed by overnight at $4^{\circ} \mathrm{C}$, testing for completion of its action. Although no subsequent study has attempted to reconcile these findings directly, they can be explained if GTP $\gamma \mathrm{S}$ can relieve PTX block but its latency or kinetics are greatly slowed. Indeed, such a slowing was demonstrated directly in an earlier study (Jakobs et al., 1984) in which activation of G-protein by GTP $\gamma \mathrm{S}$ was assayed by the inhibition of adenylate cyclase. This study found that the onset of G-protein activation was markedly slowed after PTX, from $\leq 1$ min in control cell fractions (the minimum time tested) to $\sim 5$ min after toxin treatment. Thus, all previous reports are consistent with the conclusion that PTX slows activation of G-protein by GTP $\gamma \mathrm{S}$ by several minutes. Thus, the inhibition of the presynaptic calcium current by GTP $\gamma \mathrm{S}$ after PTX block within 5-10 msec, as noted here, strongly suggests the involvement of a $G_{o} / G_{i}$-independent G-protein pathway.

Few studies have examined the spectrum of G-protein types in presynaptic nerve terminals and which of these might be involved in calcium channel modulation. We have examined the diversity and location of G-proteins at the chick calyx nerve terminal by immunocytochemistry and high-resolution imaging. All primary antibodies used in this study were characterized in detail, testing each against recombinant G-proteins to confirm specificity as well as against rat and chick neural tissue to confirm cross-reactivity. These studies indicated that $G_{\mathrm{o}}, \mathrm{G}_{\mathrm{i}}$ (Fig. 4), $\mathrm{G}_{\mathrm{q}}$ or $\mathrm{G}_{11}$ (Fig. 6), and $\mathrm{G}_{12}$ or $\mathrm{G}_{13}$ (Fig. 7) were located in the nerve terminal and at the transmitter release site regions. $\mathrm{G}_{\mathrm{s}}$ was located primarily outside the nerve terminal and synaptic cleft and exhibited little staining on the surface membrane (Fig. 8), suggesting that it is less likely to act as a primary modulator of the calcium channels. $G_{z}$ was not observed on the surface membrane but instead colocalized with the neurofilaments (Fig. 9). The functional significance of this localization is unclear, but it makes it unlikely that this G-protein modulates the calcium channels at the transmitter release site. Thus, our study identifies $\mathrm{G}_{\mathrm{q}}, \mathrm{G}_{11}, \mathrm{G}_{12}$, and $\mathrm{G}_{13}$ as possible PTXinsensitive $\mathrm{G}$-proteins capable of presynaptic calcium channel modulation at this terminal.

If, as suggested by our results, $G_{o}$ or $G_{i}$ are the only G-proteins mediating calcium channel inhibition via neurotransmitter receptors at this nerve terminal, what then is the role of the PTXinsensitive pathway? An obvious possibility is that these G-proteins are linked to an as yet untested membrane receptor pathway that we have not explored. Alternatively, the potent action of GTP $\gamma \mathrm{S}$ induces inhibition by G-proteins that are not normally involved in calcium channel modulation. However, if this was the case one might expect a much slower inhibition via the PTX-insensitive G-proteins, whereas a very rapid effect, more consistent with a membrane-delimited pathway, was noted (Fig. $5 B$ ). One exciting possibility is that mechanisms other than that initiated by metabotropic receptors can modulate the release site-associated calcium channels. Possibilities might include inhibition associated with the transmitter release steps, such as the loading or unloading of vesicles into the transmitter release site, and interactions between the presynaptic and postsynaptic cells mediated by extracellular matrix proteins. 


\section{REFERENCES}

Bean BP (1989) Neurotransmitter inhibition of neuronal calcium currents by changes in channel voltage dependence. Nature (Lond) 340:153-156.

Diversé-Pierluissi M, Dunlap K (1993) Distinct, convergent second messenger pathways modulate neuronal calcium currents. Neuron 10:753-760.

Dolphin AC (1998) Mechanisms of modulation of voltage-dependent calcium channels by G-proteins. J Physiol (Lond) 506:3-11.

Dolphin AC, Wooten JF, Scott RH, Trehtham DR (1988) Photoactivation of intracellular guanosine triphosphate analogues reduces the amplitude and slows the kinetics of voltage-activated calcium channel currents in sensory neurons. Pflügers Arch 411:628-636.

Elmslie K (1990) LHRH and GTP-gamma-S modify calcium current activation in bullfrog sympathetic neurons. Neuron 5:75-80.

Filippov AK, Webb TE, Barnard EA, Brown DA (1998) P2Y2 nucleotide receptors expressed heterologously in sympathetic neurons inhibit both N-type Ca2 + and M-type K+ currents. J Neurosci 18:5170-5179.

Grassi F, Lux H-D (1989) Voltage-dependent GABA-induced currents in chick sensory neurons. Neurosci Lett 105:113-119.

Haydon PG, Henderson E, Stanley EF (1994) Localization of individual calcium channels at the release face of a presynaptic nerve terminal. Neuron 13:1275-1280.

Hille B (1994) Modulation of ion channels by G-protein coupled receptors. Trends Neurosci 17:531-535.

Hille B, Beech DJ, Bernheim L, Mathie A, Shapiro MS, Wollmuth LP (1995) Multiple G-protein-coupled pathways inhibit N-type Ca channels of neurons. Life Sci 56:989-992.

Huff RM, Neer EJ (1986) Subunit interactions of native and ADPribosylated $\alpha 39$ and $\alpha 41$, two guanine nucleotide-binding proteins from bovine cerebral cortex. J Biol Chem 261:1105-1110.

Ikeda SR, Dunlap K (1999) Voltage-dependent modulation of N-type calcium channels: role of G-protein subunits. Adv Second Messenger Phosphoprotein Res 33:131-151.

Jakobs KH, Aktories K, Schultz G (1984) Mechanism of pertussis toxin action on the adenylate cyclase system. Eur J Biochem 140:177-181.

Jeong SW, Ikeda SR (1998) G-protein alpha subunit G alpha z couples neurotransmitter receptors to ion channels in sympathetic neurons. Neuron 21:1201-1212.

Juhaszova M, Church PJ, Blaustein MP, Stanley EF (2000) Location of calcium transporters at presynaptic terminals. Eur J Neurosci 12:839-846.

Katada T, Northup JK, Bokoch GM, Gilman AG (1984) The inhibitory guanine nucleotide-binding regulatory component of adenylate cyclase. Subunit dissociation and guanine nucleotide-dependent hormonal inhibition. J Biol Chem 259:3578-3585.

Morikawa H, Fukuda K, Mima H, Shoda T, Kato S, Mori K (1998) Nociceptin receptor-mediated $\mathrm{Ca}^{2+}$ channel inhibition and its desensitization in NG108-15 cells. Eur J Pharmacol 351:247-252.

Park D, Dunlap K (1998) Dynamic regulation of calcium influx by G-proteins, action potential waveform, and neuronal firing frequency. J Neurosci 18:6757-6766.

Stanley EF (1991) Single calcium channels on a cholinegic presynaptic nerve terminal. Neuron 7:587-591.

Stanley EF (1993) Single calcium channels and acetylcholine release at a presynaptic nerve terminal. Neuron 11:1007-1011.

Stanley EF, Drachman DB (1980) Denervation and the time course of resting membrane potential in skeletal muscle in vivo. Exp Neurol 69:253-259.

Stanley EF, Goping G (1991) Characterization of a calcium current in a vertebrate cholinergic presynaptic nerve terminal. J Neurosci 11:985-993.

Stanley EF, Mirotznik RR (1997) Cleavage of syntaxin prevents G-protein modulation of presynaptic calcium channels. Nature (Lond) 385:340-343.

Toth PT, Shekter LR, Ma GH, Philipson LH, Miller RJ (1996) Selective G-protein regulation of neuronal calcium channels. J Neurosci 16:46174624 .

Wilk-Blaszczak MA, Singer WD, Gutowski S, Sternweis PC, Belardetti F (1994) The G-protein $\mathrm{G}_{13}$ mediates inhibition of voltage-dependent calcium current by bradykinin. Neuron 13:1215-1224.

Yawo H, Chuhma N (1993) Preferential inhibition of omega-conotoxinsensitive presynaptic $\mathrm{Ca}^{2+}$ channels by adenosine autoreceptors. Nature (Lond) 365:256-258.

Yawo H, Momiyama A (1993) Re-evaluation of calcium currents in preand postsynaptic neurones of the chick ciliary ganglion. J Physiol (Lond) 460:153-172.

Zhu Y, Ikeda SR (1994) VIP inhibits N-type $\mathrm{Ca}^{2+}$ channels of sympathetic neurons via a pertussis toxin-insensitive but cholera toxin-sensitive pathway. Neuron 13:657-669. 